Article

\title{
Recovery of Platinum from Spent Petroleum Catalysts: Optimization Using Response Surface Methodology
}

\author{
Yunji Ding ${ }^{1}$, Huandong Zheng ${ }^{1}$, Jiayi Li ${ }^{1}$, Shengen Zhang ${ }^{1, *} \mathbb{C}^{\text {, Bo Liu }}{ }^{1}{ }^{(}$, , Christian Ekberg ${ }^{2}$ \\ and Zhuming Jian ${ }^{3}$ \\ 1 Institute for Advanced Materials and Technology, University of Science and Technology Beijing, \\ Beijing 100083, China; dingyunji@163.com (Y.D.); zhenghuandongUSTB@163.com (H.Z.); \\ ljy10278600@163.com (J.L.); liubo@ustb.edu.cn (B.L.) \\ 2 Nuclear Chemistry and Industrial Material Recycling, Department of Chemistry and Chemical Engineering, \\ Chalmers University of Technology, 41296 Gothenburg, Sweden; che@chalmers.se \\ 3 Yunlong Country Platinum Cui Precious Metals Technology Co., Ltd., Dali 672711, China; \\ jianzhuming@163.com \\ * Correspondence: zhangshengen@mater.ustb.edu.cn; Tel.: +86-010-6233-3375
}

Received: 14 February 2019; Accepted: 14 March 2019; Published: 20 March 2019

check for updates

\begin{abstract}
The global yield of platinum $(\mathrm{Pt})$ recovery from spent catalysts is about $30 \%$. Pt recovery from spent catalysts is one of the most significant methods to reduce its supply risk and meet future demand. The current hydro-leaching processes always involve extremely high acidity $\left(\mathrm{c}\left(\mathrm{H}^{+}\right)>6.0 \mathrm{~mol} / \mathrm{L}\right)$, causing serious environmental issues and consuming large amounts of reagents. This paper studied the recovery of $\mathrm{Pt}$ from spent petroleum catalysts in a mild leaching solution $\left(\mathrm{c}\left(\mathrm{H}^{+}\right)=1.0-2.0 \mathrm{~mol} / \mathrm{L}\right)$. The $\mathrm{HCl}$ and $\mathrm{NaCl}$ were used as leaching agents, while $\mathrm{H}_{2} \mathrm{O}_{2}$ was used for oxidation of $\mathrm{Pt}$. The leaching factors, including solid/liquid ratio (S/L), acidity, leaching temperature, and $\mathrm{H}_{2} \mathrm{O}_{2}$ usage, were studied. The leaching efficiency of $\mathrm{Pt}$ was $95.7 \%$ under the conditions of $\mathrm{S} / \mathrm{L}$ of $1: 5 \mathrm{~g} / \mathrm{mL}, \mathrm{HCl}$ of $1.0 \mathrm{~mol} / \mathrm{L}, \mathrm{NaCl}$ of $5.0 \mathrm{~mol} / \mathrm{L}, 10 \% \mathrm{H}_{2} \mathrm{O}_{2} /$ spent catalysts of $0.6 \mathrm{~mL} / \mathrm{g}$, and temperature of $90^{\circ} \mathrm{C}$ for $2 \mathrm{~h}$. The leaching kinetic of platinum fits best to the Avrami equation. The apparent activation energy for leaching platinum was $114.9 \mathrm{~kJ} / \mathrm{mol}$. Furthermore, the effects of the operating variables were assessed and optimized by employing a response surface methodology based on Box-Behnken Design. The result shows that $\mathrm{HCl}$ concentration had the greatest impact on the leaching efficiency as compared to the $\mathrm{H}_{2} \mathrm{O}_{2}$ concentration and S/L ratio. Pt leaching efficiency was increased to $98.1 \%$ at the optimized conditions of $\mathrm{HCl}$ of $1.45 \mathrm{~mol} / \mathrm{L}, \mathrm{NaCl}$ of $4.55 \mathrm{~mol} / \mathrm{L}, 10 \%$ $\mathrm{H}_{2} \mathrm{O}_{2}$ /spent catalysts of $0.66 \mathrm{~mL} / \mathrm{g}$, and S/L of $1: 4.85$. The purity of $\mathrm{Pt}$ is over $90 \%$ by the reduction of iron powder.
\end{abstract}

Keywords: spent petroleum catalysts; platinum recovery; leaching; kinetic analysis; response surface methodology

\section{Introduction}

Platinum $(\mathrm{Pt})$ is a crucial element of catalysts in converters, chemical and petroleum refining, cancer therapy, and electronics [1]. The consumption of Pt reached 210 tons in 2017 [2], which increased along with the development of technologies [3]. However, the reserves of $\mathrm{Pt}$ are geopolitically highly concentrated in South Africa, Russia, Zimbabwe, Canada, and United States, which endangers the supply to other countries and regions [4]. European Union and U.S. Department of Energy have defined $\mathrm{Pt}$ as a critical raw material depending on the risk of supply shortage. Therefore, it is essential 
to recycle Pt from secondary resources (e.g., spent catalysts, electronic waste, jewelry) to reduce primary mining and supply risks [5].

Large amounts of catalysts are used in the fluid catalytic cracking, residue fluid catalytic cracking, dehydrogenation, reforming and hydrogenation in petroleum refining, and petrochemical industries [6], which consumed about 20.2 tons of Pt in 2015 [7]. Catalysts are discarded as solid waste after deactivation resulting from fouling, poisoning, and thermal degradation/sintering [8]. Spent catalysts are important sources of Pt. However, they often contain coke, vanadium, lead, nickel, and organics that may cause serious pollution to soil and water. As a consequence, they are classified as hazardous wastes with restricted disposal in landfills. Recovery of $\mathrm{Pt}$ from spent petroleum catalysts with the consideration of environmentally is of great significance.

$\mathrm{Pt}$ is the main active component of catalysts and disperses spontaneously on the surface of the supports. Although the content of Pt loading on the catalysts is only approximately $0.05-1.0 \mathrm{wt} . \%$, it is the dominant attraction for recycling spent catalysts due to the high economic value. Hydrometallurgical and pyrometallurgical have been applied for recovering precious metals from wastes $[9,10]$. Pyrometallurgical process is normally used for concentrating Pt since their contents are extremely low in the spent catalysts. In this process, crushed spent catalysts mixed with fluxes $\left(\mathrm{Al}_{2} \mathrm{O}_{3}, \mathrm{CaO}\right.$, or $\left.\mathrm{SiO}_{2}\right)$, collector, and reductant are smelted in a blast furnace or electric furnace [11]. The support materials are oxidized or directly entered into the slag phase, while Pt forms alloy and will be collected in the metal phase. This method is more suitable for larger plants because of the huge investment and high energy consumption. Moreover, the dissolution of the alloy increases the cost and pyrometallurgical process also generates large amounts of slags.

To avoid the disadvantages of pyrometallurgical process, hydrometallurgical technologies have raised great attention [12]. Leaching step is critical when hydrometallurgy is involved. It should promote the efficient dissolution of $\mathrm{Pt}$ and minimize the leaching of supports. Chloride media are frequently used for leaching precious metals. Oxidants, such as $\mathrm{NaClO}_{3}, \mathrm{Cl}_{2}, \mathrm{H}_{2} \mathrm{O}_{2}, \mathrm{HNO}_{3}$, and $\mathrm{Cu}^{2+}$ are used to dissolve metallic PGMs (platinum group metals) into ionic state $[13,14]$. The ionic state of platinum depends on the concentrations of hydrogen and chloride ions, and temperature [15]. The complexes of $\mathrm{Pt}(\mathrm{II})$ and $\mathrm{Pt}(\mathrm{IV})$ are stable in strong acidic solution $(\mathrm{pH}<3)$. Hydrolysis may take place under reduction of free acidity (increase in $\mathrm{pH}$ value). Therefore, acidity is sufficient to activate the complexation reactions and the concentration of hydrogen ions is always over $6.0 \mathrm{~mol} / \mathrm{L}$, as shown in Table 1 . The high acidity in the leaching process causes worse working circumstances (generation of acid fog and $\mathrm{Cl}_{2}$ ) and increases the dissolution of impurities (e.g., $\mathrm{Al}_{2} \mathrm{O}_{3}, \mathrm{~V}_{2} \mathrm{O}_{5}, \mathrm{ZrO}_{2}$, etc.). Moreover, a large amount of unconsumed acid are generated in the effluent. Pt recovery is performed by chemical reduction, solvent extraction, or ion-exchange [16]. In this stage, efficient and selective separation of the desired metals from leaching solution economically is essential [17]. However, high acidic leaching reduced the efficiency of the process since large amounts of reductants are consumed by acid or the impurities decreased the selectivity of solvent extraction or ion-exchange.

The aim of this work is to increase the leaching efficiency of $\mathrm{Pt}$ at low acidic solution. First, the organics carbon deposit were removed by calcination. Hydrochloric acid is partly replaced by sodium chloride since $\mathrm{Cl}^{-}$promotes the dissolution of Pt. The calcination temperature, leaching temperature, $\mathrm{S} / \mathrm{L}$ ratio, concentration of hydrogen ion, and dosage of hydrogen peroxide were investigated. The leaching kinetic was studied, and the activation energy for Pt leaching was determined. Finally, the effects of the $\mathrm{HCl}$ concentration, $\mathrm{S} / \mathrm{L}$ ratio, and $\mathrm{H}_{2} \mathrm{O}_{2}$ usage were assessed and optimized by employing response surface methodology. 
Table 1. Some typical leaching of platinum group metals (PGMs) from spent catalysts.

\begin{tabular}{|c|c|c|c|c|c|c|}
\hline \multirow{2}{*}{ Materials } & \multicolumn{4}{|c|}{ Leaching Conditions } & \multirow{2}{*}{ Recovery Rate } & \multirow{2}{*}{ References } \\
\hline & Reagents & Temp. $\left({ }^{\circ} \mathrm{C}\right)$ & Time & $\mathrm{S} / \mathrm{L}(\mathrm{g} / \mathrm{mL})$ & & \\
\hline Spent catalysts & Aqua regia & 75 & $20 \mathrm{~min}$ & $1: 4$ & Pt $97 \%$ & [18] \\
\hline Spent auto-catalysts & aqua regia & 100 & $2 \mathrm{~h}$ & $1: 20$ & Pt $97.58 \%$ & [19] \\
\hline Super alloys & $\mathrm{H}_{2} \mathrm{SO}_{4} 800 \mathrm{~g} / \mathrm{L}, 35 \% \mathrm{H}_{2} \mathrm{O}_{2}$ & $80-90$ & $35 \mathrm{~h}$ & $1: 20$ & Pt $99.98 \%$ & [20] \\
\hline $\begin{array}{l}\text { Spent catalytic } \\
\text { converters }\end{array}$ & $\mathrm{HCl} 6 \mathrm{~mol} / \mathrm{L}, \mathrm{Cu}^{2+} 0.3 \mathrm{~mol} / \mathrm{L}$ & 80 & $4 \mathrm{~h}$ & 1:20 & Pd 95\%, Rh 86\% & [21] \\
\hline Industrial catalyst & $\mathrm{H}_{2} \mathrm{SO}_{4} 60 \%, \mathrm{NaCl} 0.1 \mathrm{~mol} / \mathrm{L}$ & 125 & $10 \mathrm{~h}$ & 1:100 & Pt $99 \%$ & [10] \\
\hline $\begin{array}{l}\text { Car catalytic } \\
\text { converters }\end{array}$ & $\begin{array}{c}\mathrm{HCl} 12 \mathrm{~mol} / \mathrm{L}, \mathrm{H}_{2} \mathrm{O}_{2} 7 \% \text { and } \\
\mathrm{H}_{2} \mathrm{SO}_{4} 2.0 \mathrm{~mol} / \mathrm{L}\end{array}$ & 90 & $6 \mathrm{~h}$ & $1: 3$ & $\mathrm{Pt}>95 \%$ & [22] \\
\hline $\begin{array}{l}\text { Scrap automotive } \\
\text { catalytic converters }\end{array}$ & $10 \mathrm{HCl}(37 \%): 1 \mathrm{H}_{2} \mathrm{O}_{2}(36 \%)$ & 80 & $2 \mathrm{~h}$ & 1:20 & Pt 95\% & [23] \\
\hline $\begin{array}{l}\text { Spent petroleum } \\
\text { catalysts }\end{array}$ & $\begin{array}{c}\mathrm{HCl} 1.45 \mathrm{~mol} / \mathrm{L}, \mathrm{NaCl} 4.55 \\
\mathrm{~mol} / \mathrm{L}, 10 \% \mathrm{H}_{2} \mathrm{O}_{2} / \mathrm{spent} \\
\text { catalysts of } 0.66 \mathrm{~mL} / \mathrm{g}\end{array}$ & 90 & $2 \mathrm{~h}$ & 1:4.85 & Pt $98.1 \%$ & This study \\
\hline
\end{tabular}

\section{Materials and Methods}

\subsection{Materials}

The employed spent petroleum catalysts were collected from Sinopec Hainan Refining and Chemical Limited Company, Danzhou, China, which were used in catalytic reforming units. The samples were ground into 10-100 $\mu \mathrm{m}$ particles before running the experiments. The content of $\mathrm{Pt}$ in the spent catalysts analyzed by ICP-OES (inductively coupled plasma-optical emission spectrometry) was $2117.5 \mathrm{~g} / \mathrm{t}$.

Hydrogen peroxide $\left(\mathrm{H}_{2} \mathrm{O}_{2}\right)$ was taken as the oxidizing agent, hydrochloric acid $(\mathrm{HCl})$ was taken as the leaching agent, sodium chloride $(\mathrm{NaCl})$ was employed to provide $\mathrm{Cl}^{-}$for platinum complexing, and iron powder was used to reduce Pt from leaching solution. $\mathrm{H}_{2} \mathrm{O}_{2}$ was diluted to $10 \%$ by deionized water before experiments. Iron powder ( -300 mesh) was used to reduce Pt from leaching solution. All are analytical reagent and purchased from Sinopharm Chemical Reagent Co., Ltd, Beijing, China. All of the solutions were prepared in deionized water.

\subsection{Experimental Procedures}

The effort of this study is to recover Pt by using less corrosive reagents and optimizing the leaching process. As the oxidation potential of $\mathrm{Pt}$ is high, it is very stable and hard to dissolve in acid solution. The formation of corresponding chloro-complex $\left(\mathrm{PtCl}_{6}{ }^{2-}\right)$ can reduce the electrode potentials of Pt. The standard electrode potential is [24]:

$$
\mathrm{PtCl}_{6}{ }^{2-}+4 \mathrm{e}^{-} \rightarrow \mathrm{Pt}+6 \mathrm{Cl}^{-} \quad\left(\varepsilon^{0}=0.74 \mathrm{~V}\right)
$$

$\mathrm{H}_{2} \mathrm{O}_{2}$ is always used to dissolve $\mathrm{Pt}$ from spent catalysts owing to its high oxidizing capacity $[19,22,23]$. The dissolution reaction of $\mathrm{Pt}$ in aqueous chloride media is given as reaction (2).

$$
\mathrm{Pt}+2 \mathrm{H}_{2} \mathrm{O}_{2}+4 \mathrm{H}^{+}+6 \mathrm{Cl}^{-} \rightarrow \mathrm{PtCl}_{6}{ }^{2-}+4 \mathrm{H}_{2} \mathrm{O}
$$

According to reaction (2), the dissolution behavior of $\mathrm{Pt}$ is determined by the concentrations of $\mathrm{H}_{2} \mathrm{O}_{2}, \mathrm{H}^{+}$, and $\mathrm{Cl}^{-}$. Higher concentrations of $\mathrm{H}_{2} \mathrm{O}_{2}, \mathrm{H}^{+}$, and $\mathrm{Cl}^{-}$promote the oxidation of $\mathrm{Pt}$, which results in higher leaching efficiency of Pt. Meanwhile, in order to decrease the dissolution of $\mathrm{Al}_{2} \mathrm{O}_{3}$ supports and generation of hazardous gases (e.g., $\mathrm{Cl}_{2}$ ), the concentration of $\mathrm{HCl}$ is strictly controlled. HSC chemistry 6.0 (Outokumpu Research Oy, Helsinki, Finland) was implemented to calculate leaching conditions of chemical equilibrium between species and draw the Eh-pH diagram of $\mathrm{Pt}-\mathrm{Cl}-\mathrm{H}_{2} \mathrm{O}$ system at $25^{\circ} \mathrm{C}$ (as shown in Figure 1). In this study, the concentrations of $\mathrm{Pt}$ and $\mathrm{Cl}^{-}$ were around $10^{-3} \mathrm{~mol} / \mathrm{L}$ and $6.0 \mathrm{~mol} / \mathrm{L}$, respectively.

The flowsheet for the recovery of $\mathrm{Pt}$ from spent catalysts is shown in Figure 2. Before leaching, spent catalysts were calcinated at $600-1000{ }^{\circ} \mathrm{C}$ for $2 \mathrm{~h}$ to remove the deposits of coke and organics. The heating rate was $10^{\circ} \mathrm{C} / \mathrm{min} . \mathrm{H}_{2} \mathrm{O}_{2}, \mathrm{HCl}$, and $\mathrm{NaCl}$ were used as the leaching agents. 


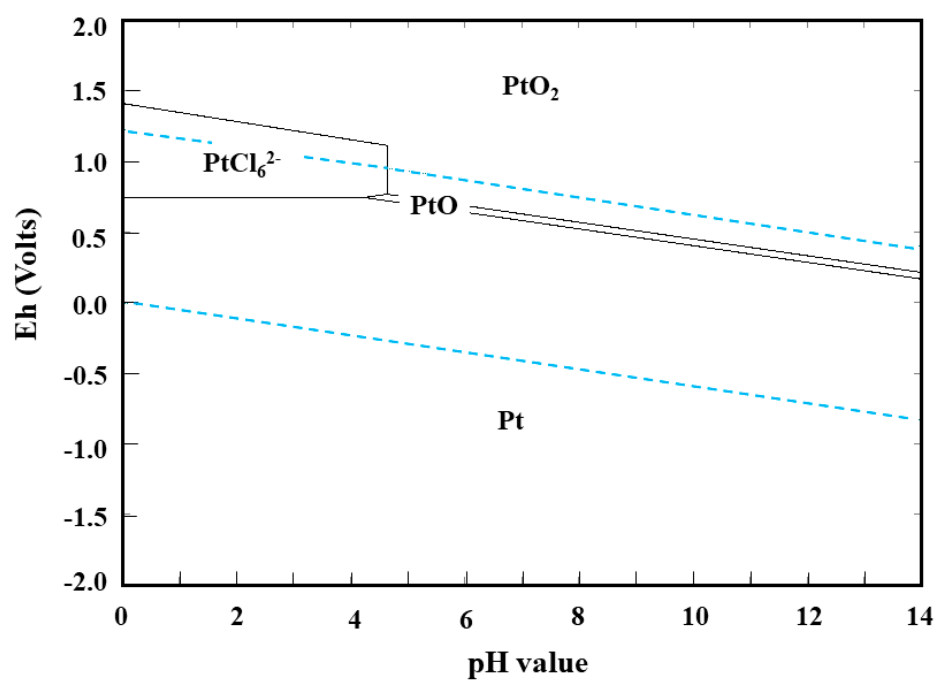

Figure 1. The Eh-pH diagram of $\mathrm{Pt}-\mathrm{Cl}-\mathrm{H}_{2} \mathrm{O}$ system at $25^{\circ} \mathrm{C}$ using $\mathrm{HSC}$ software. $(\mathrm{c}(\mathrm{Pt})=0.001 \mathrm{~mol} / \mathrm{L}$, $\left.\mathrm{c}\left(\mathrm{Cl}^{-}\right)=6.0 \mathrm{~mol} / \mathrm{L}\right)$.

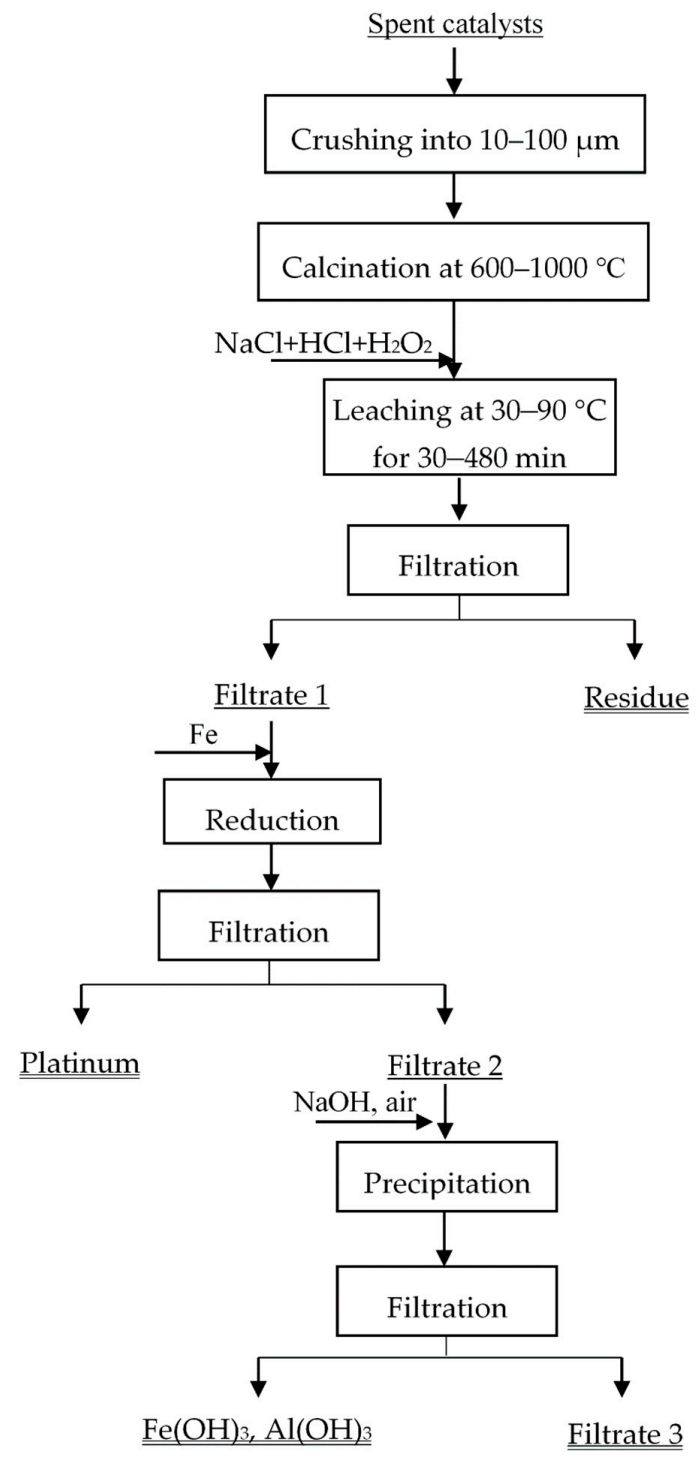

Figure 2. The process of platinum recycling from spent petroleum catalysts. 
All the leaching experiments were carried out in beaker. The beaker was placed in a water bath to control the reaction temperature. The leaching experiments were run at $30-90{ }^{\circ} \mathrm{C}$ for $30-480 \mathrm{~min}$ under magnetic stirring $(60 \mathrm{rpm})$. The beaker was covered to reduce the loss of water by evaporation. A total of $50 \mathrm{~g}$ of spent catalysts after calcination were put into the beaker, as well as the mixture solutions of $\mathrm{HCl}$ and $\mathrm{NaCl}$ at different concentrations. The total concentration of $\mathrm{Cl}^{-}$was $6.0 \mathrm{~mol} / \mathrm{L}$. $\mathrm{H}_{2} \mathrm{O}_{2}(10 \%)$ was added into the leaching system by dripping slowly after the temperature raised to target temperature. After leaching, the insoluble supports and leachate were separated via filtering. The concentration of $\mathrm{Pt}$ in leachate was used to calculate the leaching efficiencies. Finally, $\mathrm{Pt}$ was precipitated and recovered by the reduction of iron powder. The metal ions (such as $\mathrm{Fe}^{2+}$ and $\mathrm{Al}^{3+}$ ) in Filtrate 2 were precipitated by $\mathrm{NaOH}$ in air atmosphere. The main chemical component in Filtrate 3 was $\mathrm{NaCl}$, and it can be reused during the leaching process. The recovery process has low environmental impact.

\subsection{Analytical Methods}

The compositions of spent catalysts before and after calcination were analyzed by using X-ray diffraction (XRD, Rigaku D/max-2550 V, Tokyo, Japan). The chemical component of spent catalysts was analyzed by X-ray Fluorescence (XRF-1800, Shimadzu, Kyoto, Japan). Thermogravimetric analysis and differential scanning calorimetry (TG/DSC, SDT Q600, TA Instruments, New Castle, DE, USA) were utilized to determine the optimum temperature for calcination of the spent petrochemical catalysts. The measurements were performed in a flow air at a heating rate of $10^{\circ} \mathrm{C} / \mathrm{min}$. A scanning electron microscope (SEM, SU3500, Hitachi, Tokyo, Japan) associated with an energy dispersive spectrometer (EDS, GENESIS XM, EDAX Inc., Mahwah, NJ, USA) was used to observe the morphology and to determine the elemental composition of the recovered Pt. Inductively Coupled Plasma Optical Emission Spectrometer (ICP-OES Avio 200 \& Optima 8000, PerkinElmer instruments, Waltham, MA, USA) was employed to analyze the content of Pt. Before ICP-OES analysis, all the aqueous samples were co-precipitated with $\mathrm{SnCl}_{2}$ and $\mathrm{TeCl}_{4}$. For solid samples, they were digested by aqua regia at $120{ }^{\circ} \mathrm{C}$ for $6 \mathrm{~h}$ in the autoclave. Then the precipitates were dissolved by aqua regia, followed by concentrated and transferred to a $50 \mathrm{~mL}$ volumetric flsk. The error of measurement was controlled within $3 \%$.

\section{Results and Discussion}

\subsection{Characterization of Spent Catalysts}

The spent catalysts include $89.97 \% \mathrm{Al}_{2} \mathrm{O}_{3}, 2.86 \% \mathrm{Fe}_{2} \mathrm{O}_{3}, 1.74 \% \mathrm{MoO}_{3}, 1.27 \% \mathrm{Cl}, 0.97 \% \mathrm{SiO}_{2}$, and other elements are less than $0.5 \%$ (Please see in Table S2). Figure 3 shows the thermal behavior of spent catalysts during calcination in the air atmosphere. The TG curve shows that there were three main weight-loss regions at $25-390^{\circ} \mathrm{C}, 390-580^{\circ} \mathrm{C}$, and $580-1000^{\circ} \mathrm{C}$, respectively (the DTG (derivative thermogravimetry) curve is shown in Figure S1). The first weight-loss region (between 25 and $390{ }^{\circ} \mathrm{C}$ ), arises from the loss of bound water and volatile organic compound (5.17 wt.\%). The weight-loss (6.93 wt.\%) between 390 and $580{ }^{\circ} \mathrm{C}$ was because of the decomposition and combustion of organics. The exothermic DSC peaked at $504{ }^{\circ} \mathrm{C}$, which likely corresponds to the burning of organic matter. In the third weight-loss region (between $580^{\circ} \mathrm{C}$ and $1000{ }^{\circ} \mathrm{C}$ ), it was most likely due to the coke combustion (1.7 wt.\%). The color changed from dark to grey at $600{ }^{\circ} \mathrm{C}$ and to white at $1000{ }^{\circ} \mathrm{C}$ (as shown in Figure S2). Therefore, the optimum calcination temperature was between $600{ }^{\circ} \mathrm{C}$ and $1000^{\circ} \mathrm{C}$.

Figure 4 shows the XRD patterns of the spent catalysts before and after calcination at $600{ }^{\circ} \mathrm{C}$, $800{ }^{\circ} \mathrm{C}$, and $1000^{\circ} \mathrm{C}$ for $2 \mathrm{~h}$. There was no obvious difference when roasted at $600{ }^{\circ} \mathrm{C}$, and the main phase of $\mathrm{Al}_{2} \mathrm{O}_{3}$ was amorphous. When the temperature increased to $800{ }^{\circ} \mathrm{C}$, characteristic peaks of $\mathrm{Pt}$ were found. Amorphous $\mathrm{Al}_{2} \mathrm{O}_{3}$ has been transferred into $\alpha-\mathrm{Al}_{2} \mathrm{O}_{3}$ after calcination at $1000{ }^{\circ} \mathrm{C}$. The metallic $\mathrm{Pt}$ can be clearly found because of grain growth as the calcination temperature increased to $1000{ }^{\circ} \mathrm{C}$. 


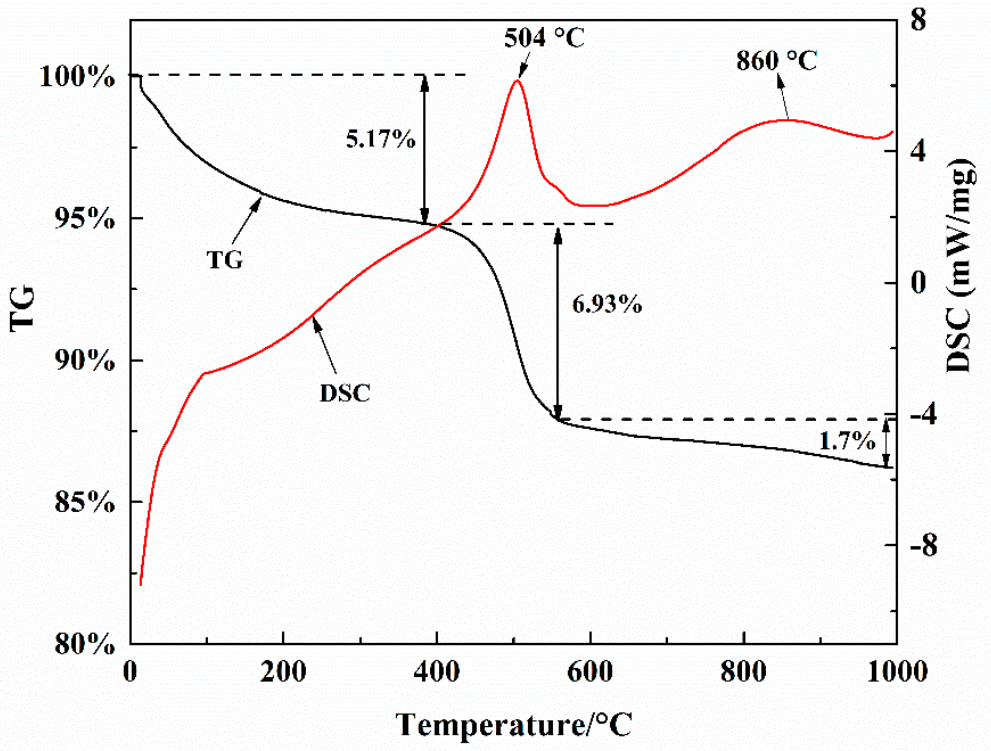

Figure 3. The thermogravimetric analysis (TG) and differential scanning calorimetry (DSC) curves of spent petrochemical catalysts.

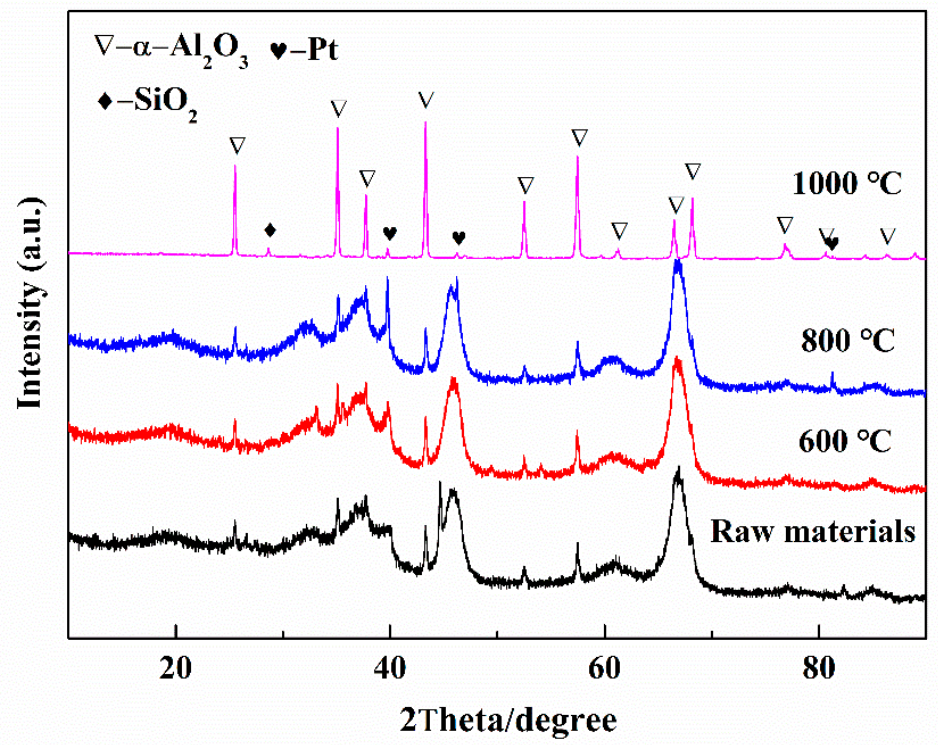

Figure 4. XRD patterns of spent petrochemical catalysts before and after calcination at $600{ }^{\circ} \mathrm{C}, 800{ }^{\circ} \mathrm{C}$, and $1000{ }^{\circ} \mathrm{C}$ for $2 \mathrm{~h}$ in air atmosphere.

\subsection{Platinum Leaching}

\subsubsection{Effect of Calcination Temperature}

As deposits of organics and carbon may absorb precious metals during leaching experiments, it is necessary to calcinate the spent catalysts before leaching. Meanwhile, $\alpha-\mathrm{Al}_{2} \mathrm{O}_{3}$ was formed after calcination, which can decrease the dissolution of $\mathrm{Al}_{2} \mathrm{O}_{3}$. Hence, the influence of calcination temperature on leaching behavior of $\mathrm{Pt}$ from spent catalysts was primarily investigated under the invariable leaching conditions of $6.0 \mathrm{~mol} / \mathrm{L} \mathrm{HCl}$, liquid/solid ratio (L/S) of $10 \mathrm{~mL} / \mathrm{g}, 10 \% \mathrm{H}_{2} \mathrm{O}_{2}$ : spent catalysts of $0.6 \mathrm{~mL} / \mathrm{g}$, and temperature of $90^{\circ} \mathrm{C}$ for $2 \mathrm{~h}$. The results presented in Table 2 clearly demonstrate the significance of calcination temperature on $\mathrm{Pt}$ leaching. 
Table 2. The leaching behavior of platinum $(\mathrm{Pt})$ at different calcination temperature (Leaching condition: $\mathrm{HCl} 6.0 \mathrm{~mol} / \mathrm{L}, \mathrm{L} / \mathrm{S}=10,10 \% \mathrm{H}_{2} \mathrm{O}_{2}$ : spent catalysts $=0.6 \mathrm{~mL} / \mathrm{g}, 90{ }^{\circ} \mathrm{C}, 2 \mathrm{~h}$ ).

\begin{tabular}{cccc}
\hline Temperature & $600{ }^{\circ} \mathrm{C}$ & $800{ }^{\circ} \mathrm{C}$ & $1000{ }^{\circ} \mathrm{C}$ \\
Leaching efficiency & $77.4 \%$ & $99.9 \%$ & $82.5 \%$ \\
Pt in leaching residue & $0.2 \%$ & $0.03 \%$ & $17.4 \%$ \\
\hline
\end{tabular}

As shown in Table 2, the leaching efficiency of Pt could be enhanced from $77.4 \%$ to $99.9 \%$ by increasing the calcination temperature from $600{ }^{\circ} \mathrm{C}$ to $800{ }^{\circ} \mathrm{C}$. However, it decreased to $82.5 \%$ when the calcination temperature was $1000{ }^{\circ} \mathrm{C}$. The content of $\mathrm{Pt}$ in the leaching residues was analyzed through aqua regia hydrothermal dissolution. However, the total $\mathrm{Pt}$ in the leachate and residue was only $77.6 \%$ when calcination at $600{ }^{\circ} \mathrm{C}$. After the residue was calcinated at $800{ }^{\circ} \mathrm{C}$, the content of $\mathrm{Pt}$ was found to be $604.5 \mathrm{~g} / \mathrm{t}$ (22.3\% of total amount in spent catalysts). The result indicated that a portion of $\mathrm{Pt}$ in spent catalysts may exist as $\mathrm{PtO}_{2}$ since it could not be dissolved in aqua regia. The relationship between Gibbs free energy of the reaction and temperature is shown in Figure S3. When the calcination temperature was above $600{ }^{\circ} \mathrm{C}, \mathrm{PtO}_{2}$ decomposed into metallic $\mathrm{Pt}$ and $\mathrm{O}_{2}$. As the calcination temperature increased to $1000{ }^{\circ} \mathrm{C}$, grain growth and recrystallization happened on the micro- and nanoscale Pt particles. The process reduced the superficial area of Pt particles and decreased their reactivity. Therefore, the optimum calcination temperature was $800^{\circ} \mathrm{C}$.

\subsubsection{Effect of $\mathrm{S} / \mathrm{L}$ and $\mathrm{HCl}$ Concentration}

In order to reduce the generation of $\mathrm{Cl}_{2}$, improve the working conditions during $\mathrm{Pt}$ leaching, and decrease the consumption of reductant in the reduction process, $\mathrm{NaCl}$ was used as a chloride source to partly replace $\mathrm{HCl}$. The effect of $\mathrm{HCl}$ concentration was evaluated in a series of tests where the total chloride ion concentration maintained constant $(6.0 \mathrm{~mol} / \mathrm{L})$, by replacing the $\mathrm{HCl}$ concentration with different $\mathrm{S} / \mathrm{L}(\mathrm{g} / \mathrm{mL})$. Figure $5 \mathrm{~A}$ illustrates the results obtained from the leaching experiments. The replacement of $\mathrm{HCl}$ by $\mathrm{NaCl}$ had significant influence on $\mathrm{Pt}$ leaching efficiency, especially when the $\mathrm{S} / \mathrm{L}$ were $1: 10$ and $1: 20 \mathrm{~g} / \mathrm{mL}$. When concentration of $\mathrm{HCl}$ was no more than $2.0 \mathrm{~mol} / \mathrm{L}$, Pt leaching efficiency was higher with a higher S/L ratio. However, the situation of Pt leaching rate was, on the contrary, at higher $\mathrm{HCl}$ concentration.
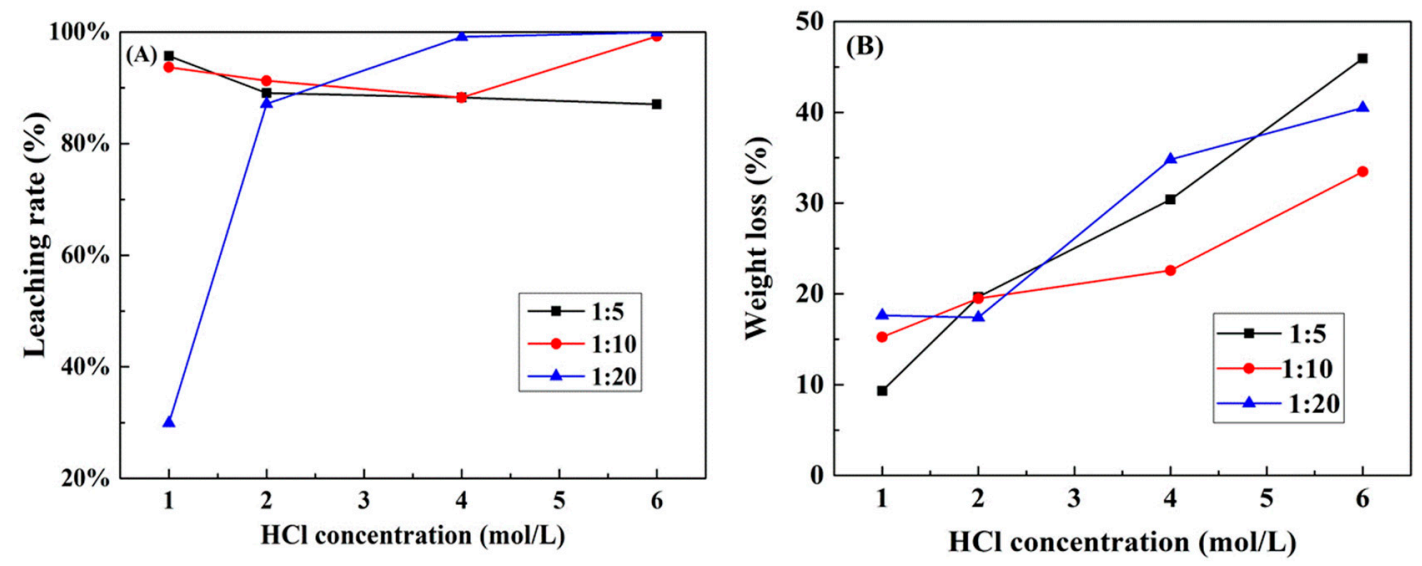

Figure 5. Effect of solid/liquid (S/L) ratio and $\mathrm{HCl}$ concentration on (A) Pt leaching rate and (B) weight loss of spent catalysts (Calcination temperature $800{ }^{\circ} \mathrm{C}, 10 \% \mathrm{H}_{2} \mathrm{O}_{2} /$ spent catalysts $=0.6 \mathrm{~mL} / \mathrm{g}$, total $\left(\mathrm{Cl}^{-}\right) 6 \mathrm{~mol} / \mathrm{L}$, leaching temperature $90^{\circ} \mathrm{C}$, leaching time $2 \mathrm{~h}$ ).

When the S/L ratio was 1:5, the leaching rate of $\mathrm{Pt}$ decreased slowly with the increasing acid concentration. The highest leaching efficiency was $95.7 \%$ when the $\mathrm{HCl}$ concentration was $1.0 \mathrm{~mol} / \mathrm{L}$. The oxidation of $\mathrm{Pt}$ mainly depended on the concentration of $\mathrm{H}_{2} \mathrm{O}_{2}$ and the dissolution of chlorine. A large amount of $\mathrm{Cl}_{2}$ was generated by the reaction of $\mathrm{H}_{2} \mathrm{O}_{2}$ and $\mathrm{HCl}$ and then discharged when the 
concentration of $\mathrm{HCl}$ was high. As the addition of $\mathrm{H}_{2} \mathrm{O}_{2}$ was constant, the oxidation of Pt would stop once $\mathrm{H}_{2} \mathrm{O}_{2}$ run out. This is the reason the leaching rate of $\mathrm{Pt}$ decreased at higher $\mathrm{HCl}$ concentrations. When the S/L was 1:10, Pt leaching rate was similar with that of $1: 5$ when $\mathrm{HCl}$ concentration was no more than $4.0 \mathrm{~mol} / \mathrm{L}$. For $6.0 \mathrm{~mol} / \mathrm{L} \mathrm{HCl}$, more than $99 \%$ of $\mathrm{Pt}$ was recovered because a higher S/L ratio can dissolve more chlorine. As the S/L ratio increased to 1:20, Pt leaching efficiency increased sharply from $30.0 \%$ to $99.9 \%$ with $\mathrm{HCl}$ concentration increasing from 1.0 to $6.0 \mathrm{~mol} / \mathrm{L}$. For $1.0 \mathrm{~mol} / \mathrm{L}$ $\mathrm{HCl}$, the concentration of $\mathrm{H}_{2} \mathrm{O}_{2}$ was the dominant factor affecting Pt leaching. However, when the concentration of $\mathrm{H}_{2} \mathrm{O}_{2}$ was less than $0.01 \mathrm{~mol} / \mathrm{L}$, Pt leaching efficiency was only 30.0\%. With the concentration of $\mathrm{HCl}$ increasing, the dissolution of chlorine started to dominate the leaching process. When $\mathrm{HCl}$ concentration was above $4.0 \mathrm{~mol} / \mathrm{L}$, over $99 \%$ of $\mathrm{Pt}$ was dissolved in the leaching system.

The weight loss of spent catalysts was calculated during the leaching process, as shown in Figure 5B. The main loss was the dissolution of $\mathrm{Al}_{2} \mathrm{O}_{3}$ since it accounted for more than $90 \%$ of the total mass of raw materials. A continuous increase of weight loss was observed as the $\mathrm{HCl}$ content increased, demonstrating that the use of $\mathrm{NaCl}$ can effectively improve the selectivity for $\mathrm{Pt}$ leaching. When the concentration of $\mathrm{HCl}$ was $1.0 \mathrm{~mol} / \mathrm{L}$, the weight loss was only $9.3 \%$ with the $\mathrm{S} / \mathrm{L}$ ratio 1:5. More than $30 \%$ of $\mathrm{Al}_{2} \mathrm{O}_{3}$ was dissolved when $\mathrm{HCl}$ concentration was $6.0 \mathrm{~mol} / \mathrm{L}$. Hence, the optimum leachant maximizing $\mathrm{Pt}$ leaching and minimizing the $\mathrm{Al}_{2} \mathrm{O}_{3}$ dissolution was composed of $1.0 \mathrm{~mol} / \mathrm{L}$ $\mathrm{HCl}$ and $5.0 \mathrm{~mol} / \mathrm{L} \mathrm{NaCl}$, and the $\mathrm{S} / \mathrm{L}$ ratio was 1:5.

\subsubsection{Effect of Leaching Temperature}

The effect of temperature on the leaching efficiency of $\mathrm{Pt}$ was also investigated. The temperature varied from 30 to $90{ }^{\circ} \mathrm{C}$, and the other conditions were $\mathrm{HCl} 1.0 \mathrm{~mol} / \mathrm{L}, \mathrm{NaCl} 5.0 \mathrm{~mol} / \mathrm{L}, 10 \%$ $\mathrm{H}_{2} \mathrm{O}_{2} /$ spent catalysts $=0.6 \mathrm{~mL} / \mathrm{g}, \mathrm{S} / \mathrm{L}=1: 5$, and leaching time of $2 \mathrm{~h}$. Figure 6 shows that the leaching rate of $\mathrm{Pt}$ increased rapidly to over $95 \%$ at $90{ }^{\circ} \mathrm{C}$. Only $25.3 \%$ of Pt was leached at $30{ }^{\circ} \mathrm{C}$. A temperature of $90^{\circ} \mathrm{C}$ is therefore suitable for the leaching process.

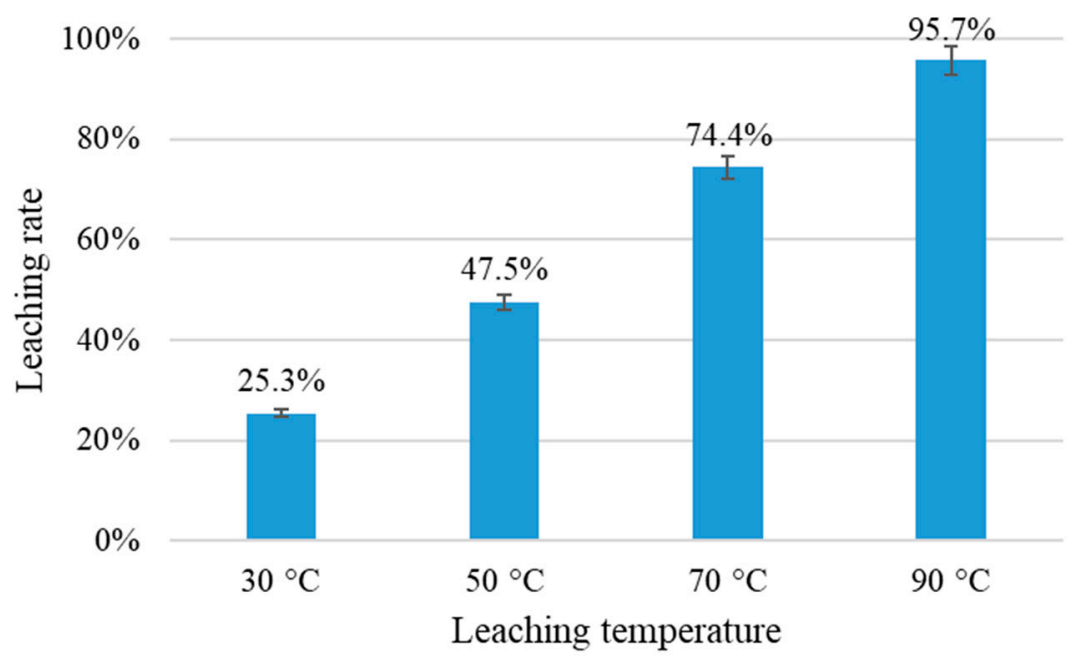

Figure 6. Leaching rates of $\mathrm{Pt}$ at different leaching temperature $(\mathrm{HCl} 1.0 \mathrm{~mol} / \mathrm{L}, \mathrm{NaCl} 5.0 \mathrm{~mol} / \mathrm{L}$, $\mathrm{S} / \mathrm{L}=1: 5,10 \% \mathrm{H}_{2} \mathrm{O}_{2}$ : spent catalysts $=0.6 \mathrm{~mL} / \mathrm{g}$ ).

\subsubsection{Effect of Hydrogen Peroxide Dosage}

Figure 7 shows the effect of the usage of $\mathrm{H}_{2} \mathrm{O}_{2}$ on Pt leaching rate for a leaching time of $2 \mathrm{~h}$ at $90{ }^{\circ} \mathrm{C}$ with the solution of $1.0 \mathrm{~mol} / \mathrm{L} \mathrm{HCl}$ and $5.0 \mathrm{~mol} / \mathrm{L} \mathrm{NaCl}$. Only 23.9\% of Pt was dissolved when the ratio of $10 \% \mathrm{H}_{2} \mathrm{O}_{2}$ : spent catalysts $(\mathrm{mL} / \mathrm{g}$ ) was 0.3 . The leaching efficiencies of Pt increased to $95.72 \%$ with the ratio of $10 \% \mathrm{H}_{2} \mathrm{O}_{2}$ : spent catalysts increasing from 0.3 to 0.6 . It indicated that more $\mathrm{H}_{2} \mathrm{O}_{2}$ could promote the oxidation of Pt. However, the leaching efficiencies decreased dramatically to $26.7 \%$ as the ratio increased to $1: 2$. As analyzed above, $\mathrm{H}_{2} \mathrm{O}_{2}$ would react with $\mathrm{HCl}$, which increased 
$\mathrm{pH}$ value of leaching solution. After the reactions finished, the $\mathrm{pH}$ values were $0.87,2.15$, and 3.52 for dosages of $10 \% \mathrm{H}_{2} \mathrm{O}_{2}$ : spent catalyst of $0.3,0.6$, and 1.2 , respectively. The dissolved $\mathrm{Pt}$ complexes were not stable and then hydrolysis, resulting in the low leaching efficiency of Pt. The addition of $\mathrm{H}_{2} \mathrm{O}_{2}$ is sufficient for the leaching process when the ratio of $10 \% \mathrm{H}_{2} \mathrm{O}_{2}$ : spent catalysts was $0.6 \mathrm{~mL} / \mathrm{g}$.

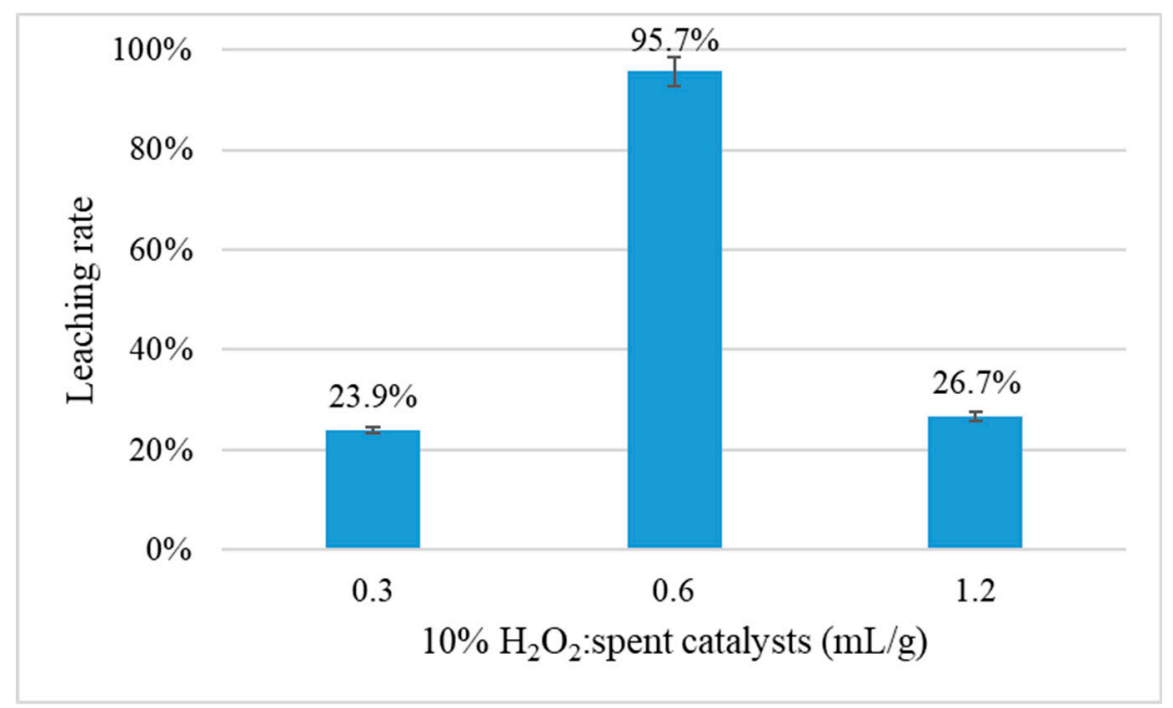

Figure 7. Effect of $\mathrm{H}_{2} \mathrm{O}_{2}$ dosage on $\mathrm{Pt}$ leaching rate $(\mathrm{HCl} 1.0 \mathrm{~mol} / \mathrm{L}, \mathrm{NaCl} 5.0 \mathrm{~mol} / \mathrm{L}, \mathrm{S} / \mathrm{L}$ ratio of 1:5, $90{ }^{\circ} \mathrm{C}$ for $\left.2 \mathrm{~h}\right)$.

\subsection{Kinetics Analysis of Platinum Leaching}

Kinetics analysis of $\mathrm{Pt}$ leaching was investigated at different temperatures $\left(30-90^{\circ} \mathrm{C}\right)$ for different times (10-480 min). The leaching conditions were as follows: $\mathrm{HCl} 1.0 \mathrm{~mol} / \mathrm{L}, \mathrm{NaCl} 5.0 \mathrm{~mol} / \mathrm{L}, \mathrm{S} / \mathrm{L}$ ratio of 1:5, $10 \% \mathrm{H}_{2} \mathrm{O}_{2}$ : spent catalysts $0.6 \mathrm{~mL} / \mathrm{g}$. The results are shown in Figure 8 .

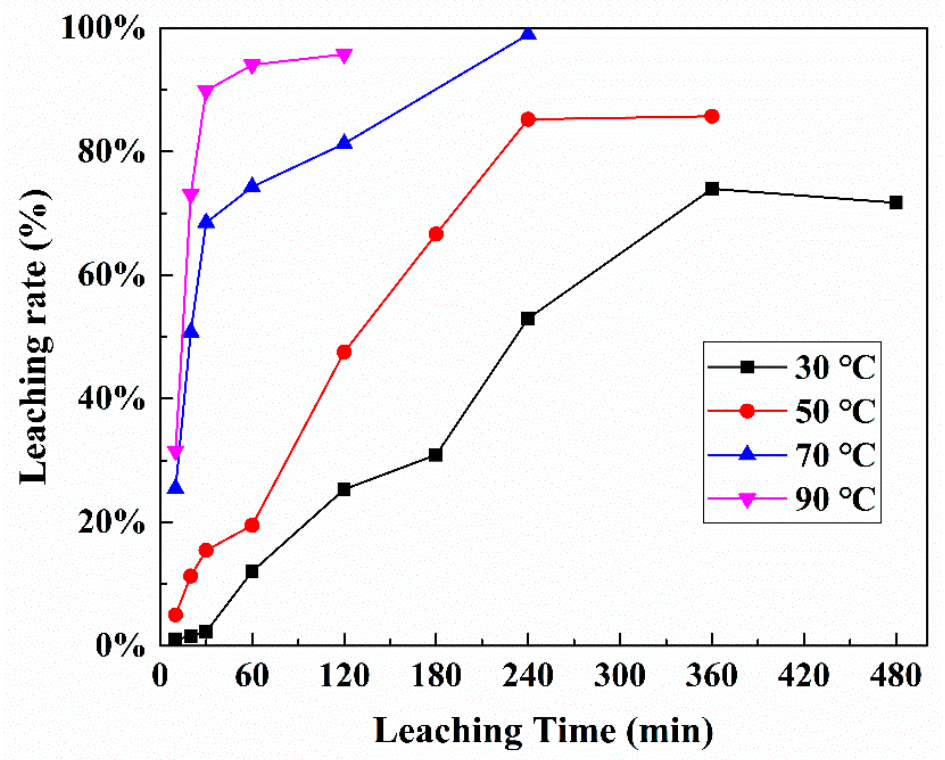

Figure 8. Leaching rate of $\mathrm{Pt}$ under different reaction temperatures and times.

Leaching Pt from spent petroleum catalysts is a solid-liquid heterogeneous reaction. The shrinking-core model and Avrami equation have been always applied to describe the leaching kinetics $[25,26]$. However, Pt leaching data showed that it did not fit various shrinking-core models 
(Figure 8, Figures S4 and S5 in Supplementary). The dissolution of Pt can be considered as the reverse behavior of its crystallization. Therefore, Pt the leaching kinetic is explained by Avrami equation:

$$
\ln [-\ln (1-\mathrm{x})]=\ln \mathrm{k}+\mathrm{n} \operatorname{lnt}
$$

where $\mathrm{x}$ is leaching rate, $\mathrm{k}$ is the reaction rate constant $\left(\mathrm{min}^{-1}\right), \mathrm{n}$ is a suitable parameter, and $\mathrm{t}$ is the leaching time (min). The plot of $\ln [-\ln (1-\mathrm{x})]$ versus $\operatorname{lnt}$ at different temperatures is shown in Figure 9 . The plot shows good linear relationships with $\mathrm{R}^{2}$ values all larger than 0.95 (Table 3). It indicates that leaching data fit well to the Avrami equation. Significantly, it can be found that the value for lnk at $90{ }^{\circ} \mathrm{C}$ is lower than that at $70{ }^{\circ} \mathrm{C}$. The leaching efficiency of Pt decreases at $90{ }^{\circ} \mathrm{C}$, which can be attributed to the decomposition of $\mathrm{H}_{2} \mathrm{O}_{2}$ when the leaching temperature is higher than $70{ }^{\circ} \mathrm{C}$.

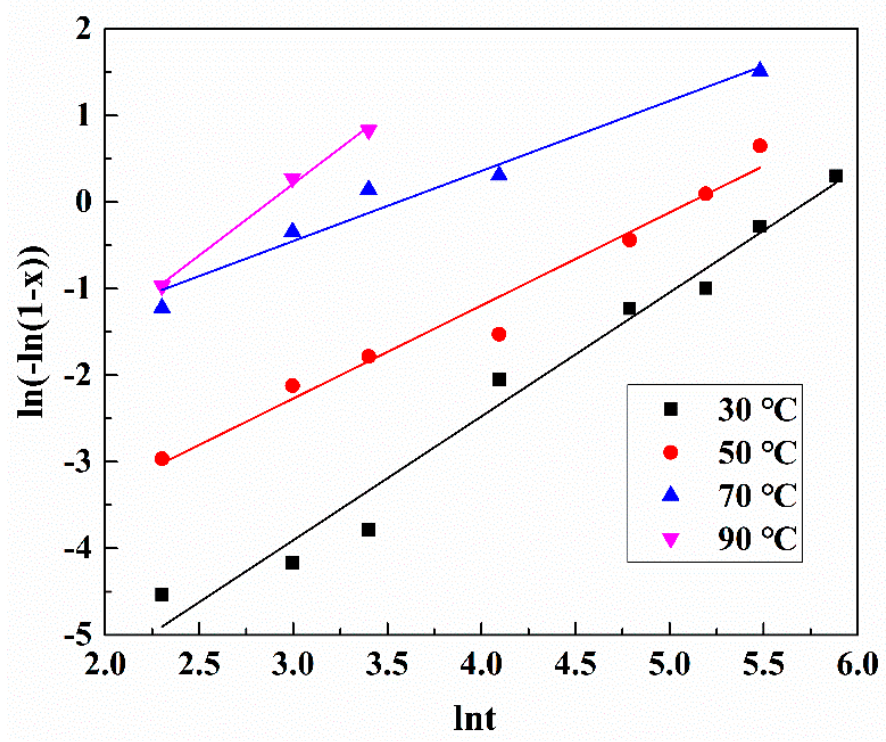

Figure 9. Plots of $\ln (-\ln (1-x))$ vs. $\operatorname{lnt}$ at different leaching temperatures.

Table 3. Kinetic parameters during the Pt leaching process using the Avrami model.

\begin{tabular}{cccc}
\hline $\mathbf{T} /{ }^{\circ} \mathbf{C}$ & $\mathbf{n}$ & $\mathbf{l n k}$ & $\mathbf{R}^{\mathbf{2}}$ \\
\hline 30 & 1.43027 & -8.19704 & 0.97262 \\
50 & 1.07385 & -5.49141 & 0.96562 \\
70 & 0.80941 & -2.88015 & 0.95073 \\
90 & 1.65294 & -4.75054 & 0.99106 \\
\hline
\end{tabular}

Therefore, in the range of $30-70{ }^{\circ} \mathrm{C}$, the relationship between the reaction rate constant and the temperature can be described by the Arrhenius equation:

$$
\mathrm{K}=\mathrm{Ae}^{-\mathrm{E}_{\mathrm{a}} / \mathrm{RT}}
$$

where $\mathrm{A}$ is the pre-exponential factor, $\mathrm{k}\left(\mathrm{min}^{-1}\right)$ is the reaction rate constant, $\mathrm{E}_{\mathrm{a}}(\mathrm{kJ} / \mathrm{mol})$ is the apparent activation energy, $\mathrm{R}(8.314 \mathrm{~J} / \mathrm{K} / \mathrm{mol})$ is the gas constant, and $\mathrm{T}(\mathrm{K})$ is the absolute temperature. The activation energy is usually calculated by the linear form of the Arrhenius equation:

$$
\operatorname{lnk}=\ln \mathrm{A}-\mathrm{E}_{\mathrm{a}} / \mathrm{RT}
$$

By plotting lnk versus 1000/T in Figure 10, the apparent activation energy for the leaching of $\mathrm{Pt}$ was $114.9 \mathrm{~kJ} / \mathrm{mol}$ in the temperature range of $303.15-343.15 \mathrm{~K}$. The relatively high values of $\mathrm{E}_{\mathrm{a}}$ indicate that the rate-controlling step of this leaching process is surface chemical reactions. 


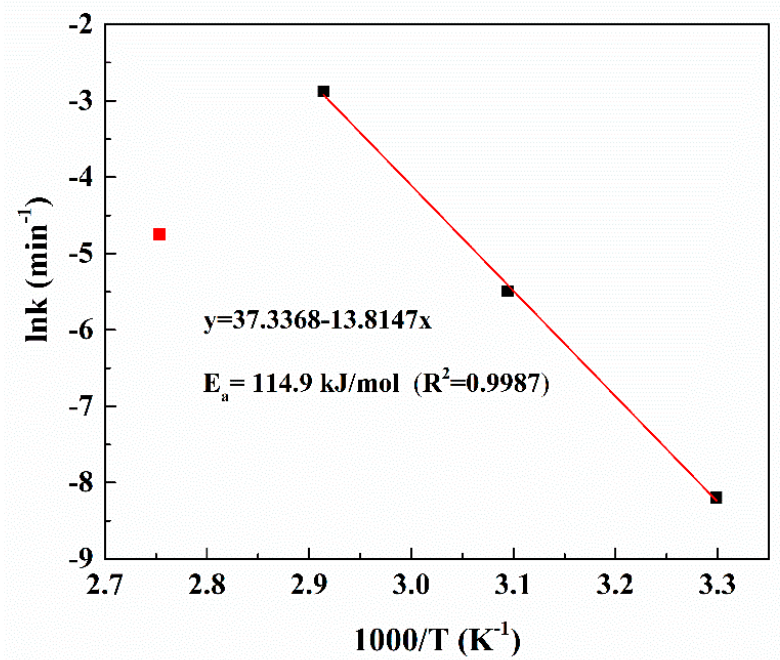

Figure 10. Arrhenius plot for leaching of $\mathrm{Pt}$ in the temperature range of 303.15-363.15 K.

\subsection{Optimization Design by Using Response Surface Methodology}

In order to investigate the interactive effects of parameters on the leaching of $\mathrm{Pt}$, response surface methodology (RSM) was employed for the optimization the effects of concentration of $\mathrm{HCl}$, dosage of $\mathrm{H}_{2} \mathrm{O}_{2}$, and $\mathrm{L} / \mathrm{S}$ ratio on Pt leaching. The design of experiments was conducted in the RSM design called Box-Behnken Design (BBD) by Design-Expert software (version 8.0.6, Stat-Ease, Inc., Minneapolis, MN, USA). The leaching rate of $\mathrm{Pt}$ was chosen as the response of these factors. Table 4 shows the coded levels and ranges of the operating variables. Coded values for the factors were used to facilitate the regression with +1 as the maximum level and -1 as the minimum level. Altogether, 17 experimental combinations are shown in Table 5, consisting of eight fractional factorials $\left(2^{\mathrm{k}}\right)$, six axial runs $(2 \mathrm{k})$, and three replicates designed at the center point, while $\mathrm{k}$ was the number of factors.

Table 4. Experimental design for Pt leaching, and their coded and actual levels.

\begin{tabular}{cccc}
\hline \multirow{2}{*}{ Factors } & \multicolumn{3}{c}{ Coded Levels } \\
\cline { 2 - 4 } & $\mathbf{- 1}$ & $\mathbf{0}$ & $\mathbf{1}$ \\
\hline $\mathrm{A}: \mathrm{HCl}$ concentration $(\mathrm{mol} / \mathrm{L})$ & 0.5 & 1 & 1.5 \\
$\mathrm{~B}: 10 \% \mathrm{H}_{2} \mathrm{O}_{2} /$ spent catalysts $(\mathrm{mL} / \mathrm{g})$ & 0.3 & 0.6 & 0.9 \\
$\mathrm{C}:$ Liquid/solid ratio & 3 & 5 & 7 \\
\hline
\end{tabular}

Table 5. Factors and response values of Pt leaching.

\begin{tabular}{|c|c|c|c|c|}
\hline Run & $\begin{array}{c}\text { Factor } 1 \\
\mathrm{HCl} \text { Concentration (mol/L) }\end{array}$ & $\begin{array}{c}\text { Factor } 2 \\
\mathrm{H}_{2} \mathrm{O}_{2} \text { Dosage }(\mathrm{mL} / \mathrm{g}) \\
\end{array}$ & $\begin{array}{c}\text { Factor } 3 \\
\text { Liquid/Solid (L/S) }\end{array}$ & $\begin{array}{c}\text { Response } \\
\text { Pt Leaching Rate (\%) }\end{array}$ \\
\hline 1 & 1.0 & 0.3 & 3 & $13.9 \%$ \\
\hline 2 & 0.5 & 0.3 & 5 & $19.8 \%$ \\
\hline 3 & 1.0 & 0.3 & 7 & $33.9 \%$ \\
\hline 4 & 1.5 & 0.3 & 5 & $95.7 \%$ \\
\hline 5 & 1.0 & 0.6 & 5 & $93.9 \%$ \\
\hline 6 & 1.0 & 0.9 & 3 & $41.1 \%$ \\
\hline 7 & 1.0 & 0.6 & 5 & $94.4 \%$ \\
\hline 8 & 1.0 & 0.6 & 5 & $95.1 \%$ \\
\hline 9 & 1.0 & 0.9 & 7 & $21.7 \%$ \\
\hline 10 & 0.5 & 0.9 & 5 & $24.7 \%$ \\
\hline 11 & 1.0 & 0.6 & 5 & $94.8 \%$ \\
\hline 12 & 1.5 & 0.9 & 5 & $68.5 \%$ \\
\hline 13 & 1.5 & 0.6 & 7 & $92.3 \%$ \\
\hline 14 & 0.5 & 0.6 & 3 & $7.4 \%$ \\
\hline 15 & 1.0 & 0.6 & 5 & $95.2 \%$ \\
\hline 16 & 0.5 & 0.6 & 7 & $13.4 \%$ \\
\hline 17 & 1.5 & 0.6 & 3 & $24.4 \%$ \\
\hline
\end{tabular}


The response values were recorded from the results of leaching experiments, which vary from $7.4 \%$ to $95.7 \%$. The analysis of ANOVA is given in Table 6, indicating that Pt leaching-rate response surface quadratic model was significant at an $F$ value of 17.50 and a $P$ value of 0.0005 . $F$ value for lack of fit was significant when the $F$ value and $p$-value were 1137.16 and $<0.0001$, respectively. An adequate precision ratio of 10.620 (>4) indicated an adequate signal-to-noise ratio and indicated that this model can be used to navigate the design space [27]. The $\mathrm{R}^{2}$ value of 0.9574 showed that $95.7 \%$ of the variations that occurred for Pt leaching were explained by the proposed model. The close values of $R^{2}(0.9574)$ and adjusted $R^{2}(0.9027)$ indicated the proposed model was adequate for predicting $\mathrm{Pt}$ leaching efficiency.

Table 6. ANOVA results of reduced quadratic model for the Pt leaching efficiency.

\begin{tabular}{cccccc}
\hline Source & Sun of Squares & df & Mean Square & $\boldsymbol{F}$ Value & $p$ Value \\
\hline Model & 20710.34 & 9 & 695.56 & 47.52 & $<0.0001$ \\
A & 5805.03 & 1 & 3892.27 & 265.93 & $<0.0001$ \\
B & 6.28 & 1 & 3.39 & 0.23 & 0.6449 \\
C & 695.09 & 1 & 123.32 & 8.43 & 0.0229 \\
AB & 258.73 & 1 & 3.31 & 0.23 & 0.6488 \\
AC & 958.21 & 1 & 58.98 & 4.03 & 0.0847 \\
BC & 388.09 & 1 & 7.05 & 0.48 & 0.5101 \\
A $^{2}$ & 1350.30 & 1 & 2071.80 & 141.55 & $<0.0001$ \\
B $^{2}$ & 2553.33 & 1 & 13.57 & 0.93 & 0.3677 \\
Residual & 7571.48 & 1 & 57.17 & 3.91 & 0.0887 \\
Lack of fit & 920.57 & 7 & 14.64 & & $<0.0001$ \\
Pure error & 919.49 & 3 & 34.05 & 453.29 & \\
Cor total & 1.08 & 4 & 0.075 & & \\
\hline
\end{tabular}

The impacts of $\mathrm{HCl}$ concentration (0.0005 of $p$-value) and L/S (0.0551 of $p$-value) were greater than that of $10 \% \mathrm{H}_{2} \mathrm{O}_{2}$ /spent catalysts (0.8332 of $p$-value). The quadratic polynomial equation in terms of coded values to predict Pt leaching efficiency are presented in equation (6), where y is the response factor of Pt leaching. The equation shows that the linear factors of $\mathrm{A}$ and $\mathrm{C}$ and the interaction $\mathrm{AC}$ had positive influences on the response, whereas negative coefficients indicated unfavorable effects on $\mathrm{Pt}$ leaching efficiency.

$$
Y=94.68+26.94 A-0.89 B+9.32 C-8.04 A B+15.48 A C-9.85 B C-17.91 A^{2}-24.63 B^{2}-42.41 C^{2}
$$

The interaction effects of two factors on Pt leaching rate were illustrated through 3D response surface 2D contour plots, as shown in Figure 11. Pt leaching rate was more sensitive to $\mathrm{HCl}$ concentration and liquid/solid ratio than $\mathrm{H}_{2} \mathrm{O}_{2}$ dosage. The leaching rate of $\mathrm{Pt}$ increased with $\mathrm{HCl}$ concentration. As shown in Figure $11 \mathrm{~b}$, when $\mathrm{B}$ and $\mathrm{C}$ fixed at $0.60 \mathrm{~mL} / \mathrm{g}$ and $5 \mathrm{~mL} / \mathrm{g}$, respectively, increasing A from 0.5 to $1.5 \mathrm{~mol} / \mathrm{L}$, the leaching rate of $\mathrm{Pt}$ increased from $50.1 \%$ to $100 \%$. Pt leaching rate first increased and decreased afterwards with the increasing of the liquid/solid ratio, as shown in Figure $11 \mathrm{~d}$. However, the dosage of $\mathrm{H}_{2} \mathrm{O}_{2}$ ranging from 0.3 to $0.9 \mathrm{~mL} / \mathrm{g}$ hardly influenced the leaching efficiency of $\mathrm{Pt}$, as shown in Figure 11e.

Numerical optimization was conducted with the maximum goal of $\mathrm{Pt}$ leaching rate, minimum goal of L/S, and lower consumption of reagents. The best leaching efficiency of Pt was $100 \%$ under the conditions of $1.45 \mathrm{~mol} / \mathrm{L}, 10 \% \mathrm{H}_{2} \mathrm{O}_{2} /$ spent catalysts of $0.66 \mathrm{~mL} / \mathrm{g}$, and $\mathrm{L} / \mathrm{S}$ of $4.85: 1$. Based on the above results, a test was carried out under the optimal conditions. The leaching rate of $\mathrm{Pt}$ was $98.1 \%$, which agreed with the prediction. 
(a)

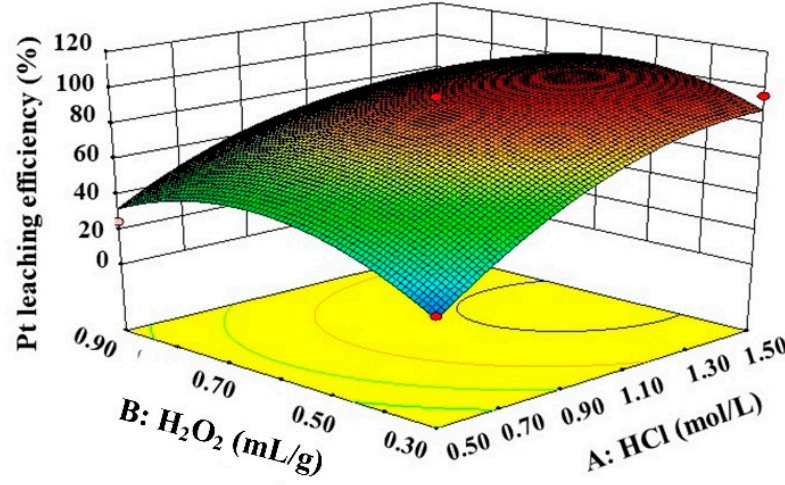

(c)

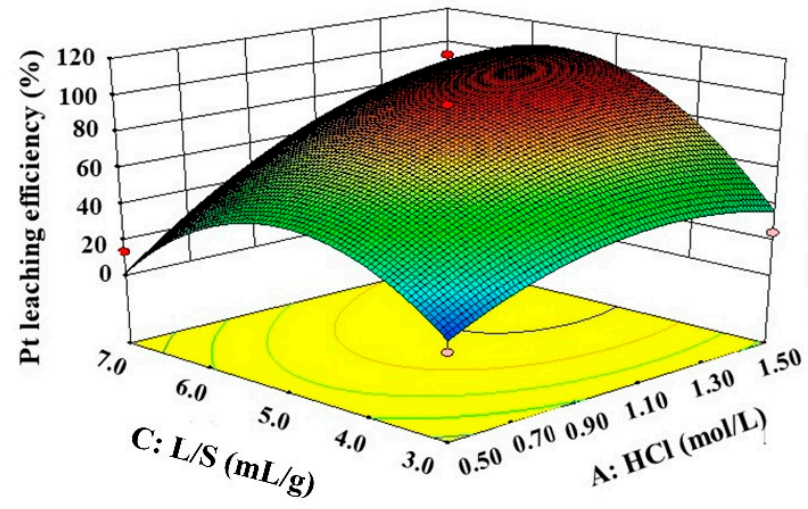

(e)

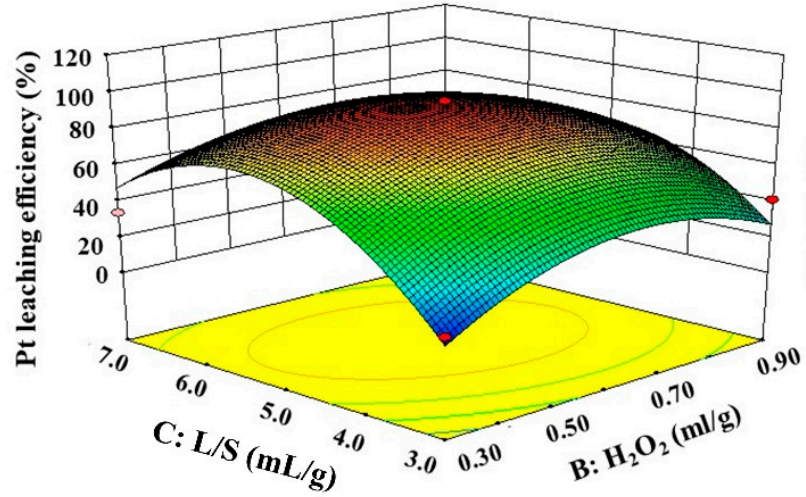

(b)

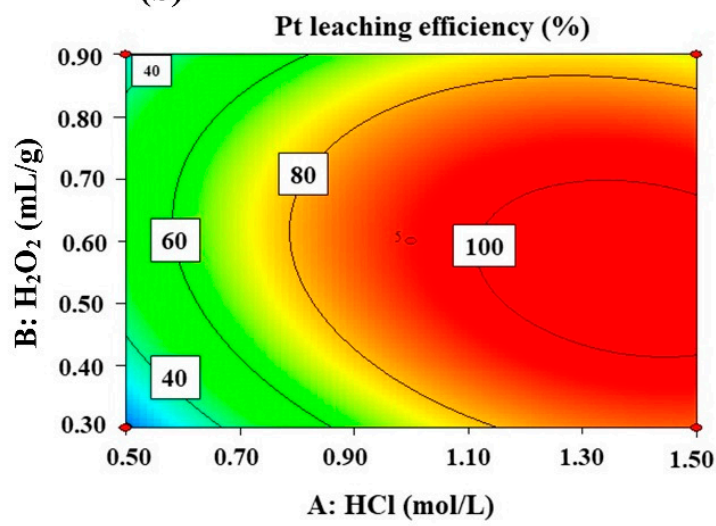

(d)

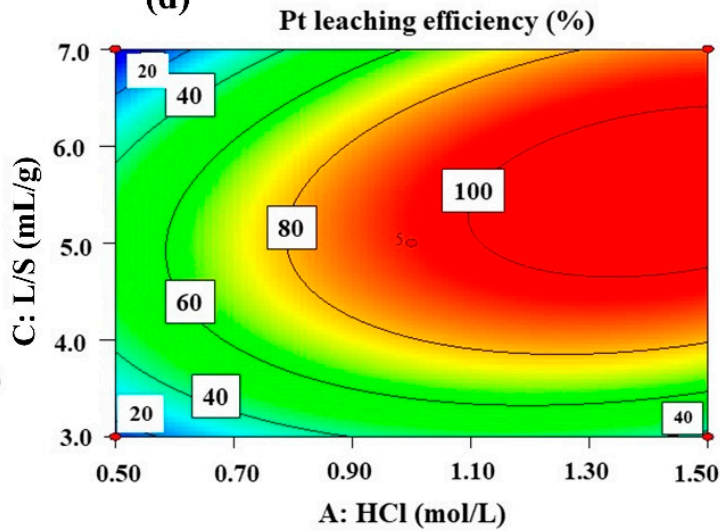

(f)

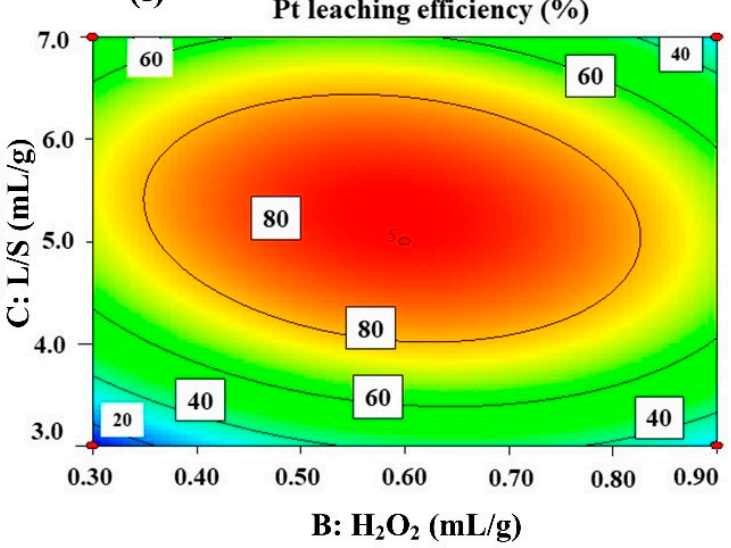

Figure 11. The 3D response surface and $2 \mathrm{D}$ contour plots for the interaction effects on the platinum leaching rate. In $(\mathbf{a}, \mathbf{b}), \mathrm{C}: \mathrm{L} / \mathrm{S}=5.0 \mathrm{~mL} / \mathrm{g}$; in $(\mathbf{c}, \mathbf{d}), \mathrm{B}: 10 \% \mathrm{H}_{2} \mathrm{O}_{2} /$ spent catalysts $=0.6 \mathrm{~mL} / \mathrm{g}$; and in $(\mathbf{e}, \mathbf{f}), \mathrm{A}: \mathrm{c}(\mathrm{HCl})=1.0 \mathrm{~mol} / \mathrm{L}$.

\subsection{Recovery of Platinum from Leaching Solution}

$\mathrm{Pt}$ was dissolved in the solution by $\mathrm{HCl}-\mathrm{NaCl}-\mathrm{H}_{2} \mathrm{O}_{2}$ leaching. After filtration, it was reduced as metallic Pt particles by iron powder. The effects of the $\mathrm{HCl}$ concentration and $\mathrm{S} / \mathrm{L}$ ratio on the consumption of reductant were investigated at $90{ }^{\circ} \mathrm{C}$, and the results are shown in Figure 12. During the reduction process, the key problem was to determine the reaction end point. By adding $5.0 \mathrm{~mL}$ of $4.0 \mathrm{~mol} / \mathrm{L} \mathrm{HCl}, 3.0 \mathrm{~mL}$ of $0.4 \mathrm{~mol} / \mathrm{L} \mathrm{SnCl}_{2}$, and $5.0 \mathrm{~mL}$ of ethyl acetate into $5.0 \mathrm{~mL}$ of the leaching solution in turn, the result is shown in Figure S6 with different usage of Fe. If the solution contains any $\left[\mathrm{PtCl}_{n}\right]^{2-\mathrm{n}}(\mathrm{n}=1-4)$, it will be extracted and enters into organic phase (ethyl acetate). The color in ethyl acetate phase will change from yellow-orange to colorless once the reduction reaction is over. Hence, 
we added the iron powder slowly in the Pt leaching solution and checked the end point of reduction reaction in time until the ethyl acetate phase was colorless. The concentration of Pt remaining in leaching solution varied from $0.45 \mathrm{mg} / \mathrm{L}$ to $1.03 \mathrm{mg} / \mathrm{L}$, indicating that the recovery rates of $\mathrm{Pt}$ were over $99.5 \%$.

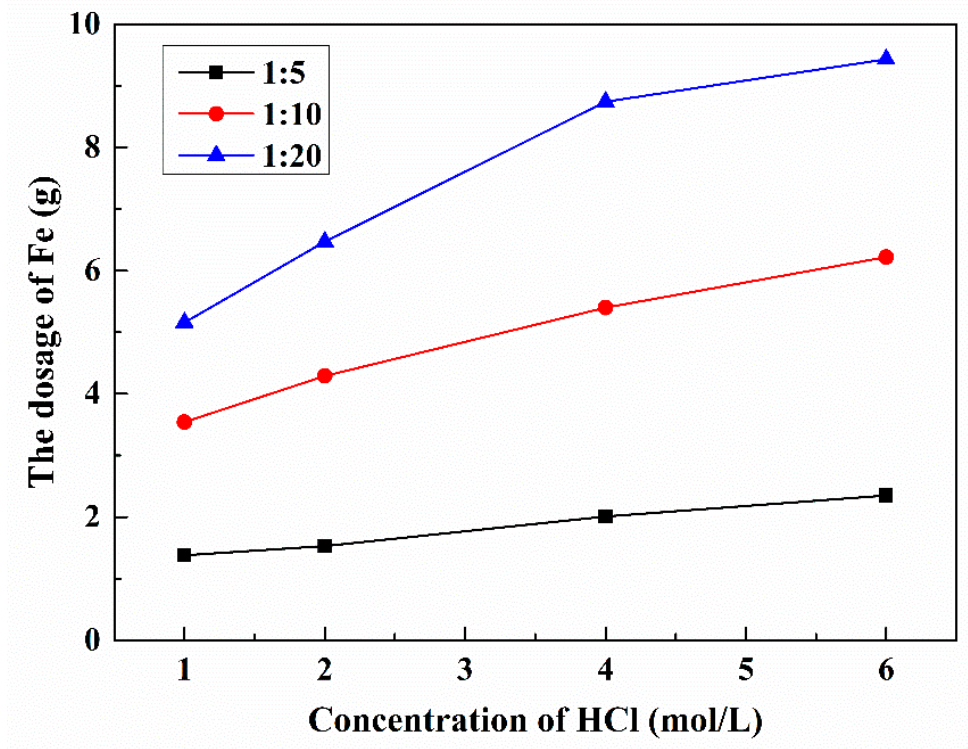

Figure 12. Effect of $\mathrm{HCl}$ concentration and $\mathrm{S} / \mathrm{L}$ ratio on the consumption of Fe during Pt recovery at $90^{\circ} \mathrm{C}$.

As we can see from Figure 12, the initial $\mathrm{HCl}$ concentration and S/L ratio affected the usage of Fe significantly. The volume of leaching solution and concentration of Pt was shown in Table S3. According to the stoichiometric molar ratio of $\mathrm{Pt}$ and $\mathrm{Fe}(\mathrm{Pt}: \mathrm{Fe}=1: 2)$, the stoichiometric amount of iron needed to reduce platinum was about $0.07 \mathrm{~g}$. The consumption of Fe was found to increase with increasing $\mathrm{HCl}$ concentration, which was more obvious when it was below $4.0 \mathrm{~mol} / \mathrm{L}$. In fact, most reductant reacts with $\mathrm{HCl}$, and higher $\mathrm{HCl}$ concentration will consume more iron powder. The usage of Fe increased proportionally with the increasing $\mathrm{S} / \mathrm{L}$ ratio. For example, the used Fe was about 20 times more than stoichiometric amount of iron needed when the S/L of 1:5, $\mathrm{HCl}$ concentration of $1.0 \mathrm{~mol} / \mathrm{L}$, and its consumption was over 100 times when the $\mathrm{S} / \mathrm{L}$ of $1: 20$, concentration of $6.0 \mathrm{~mol} / \mathrm{L}$. This is in accordance with the previous results since higher $\mathrm{S} / \mathrm{L}$ ratio means more $\mathrm{HCl}$ in the solution. To reduce the consumption of reducing agent in recovery process, $1.0 \mathrm{~mol} / \mathrm{L} \mathrm{HCl}, 5.0 \mathrm{~mol} / \mathrm{L} \mathrm{NaCl}$, and $\mathrm{S} / \mathrm{L}$ ratio of 1:5 were selected as the optimal lixivium and $\mathrm{S} / \mathrm{L}$ ratio, respectively. The conditions were consistent with the leaching experiments.

The recovered Pt was analyzed by SEM and EDS, as shown in Figure 13. The SEM image clearly shows that the samples were irregular particles (about $10 \mu \mathrm{m}$ ). The EDS result indicates the main component of the samples was metallic $\mathrm{Pt}$, which accounts for over $93 \%$ of the total weight. Impurities, such as $\mathrm{Al}$ and $\mathrm{O}$ elements, were detected in the particles because of the absorption of little leaching solution. 


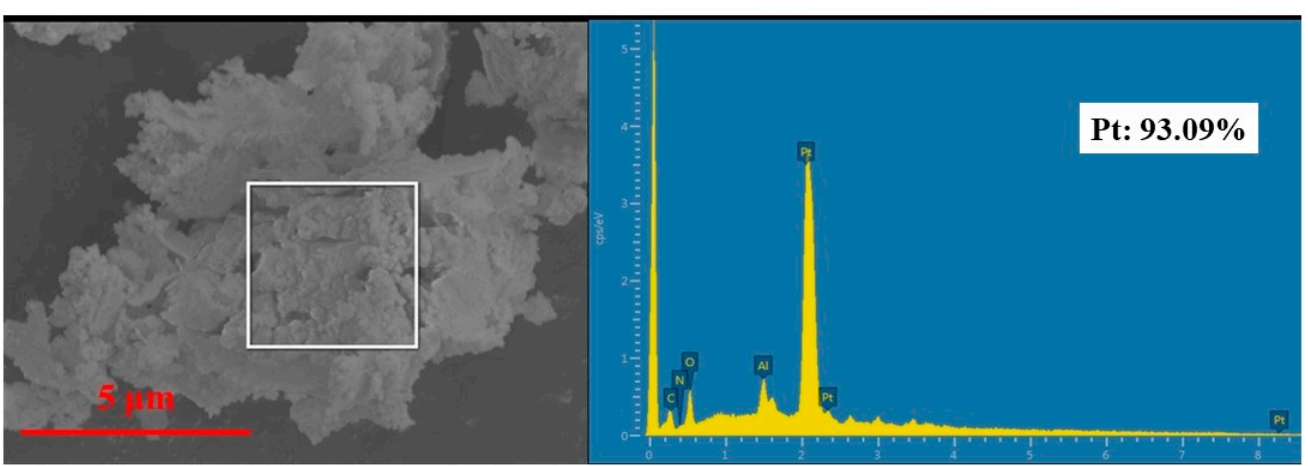

Figure 13. SEM-EDS of recovered Pt particles.

\section{Conclusions}

Recovery of $\mathrm{Pt}$ from spent petroleum catalysts was investigated. The main parameters affecting the Pt chloride leaching were systematically assessed, aiming to achieve a satisfactory recovery rate of $\mathrm{Pt}$ with minimum reagent consumption and environmental pollution.

Calcination pretreatment not only removed the coke and organics, but also decomposed $\mathrm{PtO}_{2}$ when the temperature was over $600{ }^{\circ} \mathrm{C}$, and enhanced the leaching efficiency of Pt. The grain growth of Pt at $1000{ }^{\circ} \mathrm{C}$ decreased its chemical reactivity. Therefore, the optimum calcination temperature was $800{ }^{\circ} \mathrm{C}$. Pt leaching rate was increased steadily with the increasing leaching temperature and reached $95.72 \%$ at $90{ }^{\circ} \mathrm{C}$ (other conditions being $1.0 \mathrm{~mol} / \mathrm{L} \mathrm{HCl}, 5.0 \mathrm{~mol} / \mathrm{L} \mathrm{NaCl}, \mathrm{S} / \mathrm{L}$ of $1: 5,10 \% \mathrm{H}_{2} \mathrm{O}_{2}$ : spent catalysts of $0.6 \mathrm{~mL} / \mathrm{g}$ ). When $10 \% \mathrm{H}_{2} \mathrm{O}_{2}$ : spent catalysts was $0.6 \mathrm{~mL} / \mathrm{g}$, the dosage of $\mathrm{H}_{2} \mathrm{O}_{2}$ was optimal since the acidity decreased with $\mathrm{H}_{2} \mathrm{O}_{2}$ addition. Pt leaching rate increased with $\mathrm{S} / \mathrm{L}$ increasing when the concentration of $\mathrm{H}^{+}$was $\geq 4.0 \mathrm{~mol} / \mathrm{L}$, while decreased in low acidity $(<4.0 \mathrm{~mol} / \mathrm{L})$. The dissolution of supports was only $9.3 \%$ when leached in $1.0 \mathrm{~mol} / \mathrm{L} \mathrm{HCl}$ and $5.0 \mathrm{~mol} / \mathrm{L} \mathrm{NaCl}$ with $\mathrm{L} / \mathrm{S}$ of $5 \mathrm{~mL} / \mathrm{g}$.

The operating variables on platinum leaching efficiency were optimized by employing a response surface methodology. Pt leaching efficiency was over $98 \%$ under the optimized conditions: $\mathrm{HCl}$ of $1.45 \mathrm{~mol} / \mathrm{L}, \mathrm{NaCl}$ of $4.55 \mathrm{~mol} / \mathrm{L}, 10 \% \mathrm{H}_{2} \mathrm{O}_{2} /$ spent catalysts of $0.66 \mathrm{~mL} / \mathrm{g}$, and $\mathrm{L} / \mathrm{S}$ of 4.85:1. Meanwhile, $\mathrm{HCl}$ concentration had the greatest impact on the leaching efficiency as compared to the $\mathrm{H}_{2} \mathrm{O}_{2}$ concentration and $\mathrm{L} / \mathrm{S}$ ratio.

More than $99.5 \%$ of $\mathrm{Pt}$ was reduced from leaching solution by iron powder. The consumption of iron powder increased with both higher acidity and L/S ratio. The leaching kinetic of $\mathrm{Pt}$ can be explained by the Avrami equation. The activation energy for leaching $\mathrm{Pt}$ was $114.9 \mathrm{~kJ} / \mathrm{mol}$ and the process was controlled by the chemical reaction.

Supplementary Materials: The following are available online at http://www.mdpi.com/2075-4701/9/3/354/s1, Figure S1: The DTG curve of spent petrochemical catalysts; Figure S2: Color changes of spent catalysts at different calcination temperature; Figure S3: The relationship between Gibbs free energy of the decomposition of $\mathrm{PtO}_{2}$ and temperature; Figure S4: Plots of $1-(1-x)^{1 / 3}$ vs. time under different leaching temperatures; Figure S5: Plots of $1-3(1-x)^{2 / 3}+2(1-x)$ vs. time under different leaching temperatures; Figure S6: The color changes in ethyl acetate phase with different usage of Fe. Table S1: The Gibbs free energy of the decomposition of $\mathrm{PtO}_{2} ; \mathrm{Table}$ S2: The XRF analysis of spent catalysts (before calcination) in form of oxides; Table S3: The volume of leaching solution and concentration of $\mathrm{Pt}$.

Author Contributions: Conceptualization, S.Z. and Y.D.; methodology, H.Z.; validation J.L. and B.L.; formal analysis, C.E.; investigation, Y.D.; resources, Z.J.; data curation, Y.D.; writing-original draft preparation, Y.D.; supervision, S.Z.; funding acquisition, S.Z.

Funding: This research was sponsored by the National Natural Science Foundation of China (51472030, 51672024 and 515102014).

Conflicts of Interest: The authors declare no conflict of interest. 


\section{References}

1. Hennebel, T.; Boon, N.; Maes, S.; Lenz, M. Biotechnologies for critical raw material recovery from primary and secondary sources: R\&D priorities and future perspectives. New Biotechnol. 2015, 32, 121-127.

2. US Geological Survey (USGS). Platinum-Group Metals Statistics and Information. In Mineral Commodity Summaries; 2018. Available online: https:/ / minerals.usgs.gov/minerals/pubs/commodity/platinum/mcs2018-plati.pdf (accessed on 2 February 2019).

3. Sverdrup, H.U.; Ragnarsdottir, K.V. A system dynamics model for platinum group metal supply, market price, depletion of extractable amounts, ore grade, recycling and stocks-in-use. Resour. Conserv. Recycl. 2016, 114, 130-152. [CrossRef]

4. Graedel, T.E.; Harper, E.M.; Nassar, N.T.; Nuss, P.; Reck, B.K. Criticality of metals and metalloids. Proc. Natl. Acad. Sci. USA 2015, 112, 4257-4262. [CrossRef] [PubMed]

5. Westerhoff, P.; Lee, S.; Yang, Y.; Gordon, G.W.; Hristovski, K.; Halden, R.U.; Herckes, P. Characterization, Recovery Opportunities, and Valuation of Metals in Municipal Sludges from U.S. Wastewater Treatment Plants Nationwide. Environ. Sci. Technol. 2015, 49, 9479-9488. [CrossRef] [PubMed]

6. Ferella, F.; Innocenzi, V.; Maggiore, F. Oil refining spent catalysts: A review of possible recycling technologies. Resour. Conserv. Recycl. 2016, 108, 10-20. [CrossRef]

7. US Geological Survey (USGS). Platinum-Group Metals Statistics and Information. In Minerals Yearbook of Platinum-Group Metals; 2015. Available online: https://minerals.usgs.gov/minerals / pubs/commodity / platinum/myb1-2015-plati.pdf (accessed on 2 February 2019).

8. Marafi, M.; Stanislaus, A. Spent catalyst waste management: A review: Part I-Developments in hydro-processing catalyst waste reduction and use. Resour. Conserv. Recycl. 2008, 52, 859-873. [CrossRef]

9. Akcil, A.; Vegliò, F.; Ferella, F.; Okudan, M.D.; Tuncuk, A. A review of metal recovery from spent petroleum catalysts and ash. Waste Manag. 2015, 45, 420-433. [CrossRef]

10. Mahmoud, M.H.H. Leaching platinum-group metals in a sulfuric acid/chloride solution. JOM 2003, 55, 37-40. [CrossRef]

11. He, X.; Li, Y.; Wu, X.; Zhao, Y.; Wang, H.; Liu, W. Study on the Process of Enrichment Platinum Group Metals by Plasma Melting Technology. Precious Met. 2016, 37, 1-5.

12. Rumpold, R.; Antrekowitsch, J. Recycling of platinum group metals from automotive catalysts by an acidic leaching process. S. Afr. Inst. Min. Metall. Platinum 2012, 1, 695-714.

13. Jha, M.K.; Lee, J.C.; Kim, M.S.; Jeong, J.; Kim, B.S.; Kumar, V. Hydrometallurgical Recovery/Recycling of Platinum by the Leaching of Spent Catalysts: A review. Hydrometallurgy 2013, 133, 23-32. [CrossRef]

14. Sun, P.P.; Lee, M.S. Separation of Pt (IV) and Pd (II) from the loaded Alamine 336 by stripping. Hydrometallurgy 2011, 109, 181-184. [CrossRef]

15. Hubicki, Z.; Wójcik, G. Studies of removal of platinum (IV) ion microquantities from the model solutions of aluminium, copper, iron, nickel and zinc chloride macroquantities on the anion exchanger Duolite S 37. J. Hazard. Mater. 2006, 136, 770-775. [CrossRef]

16. Marinho, R.S.; Afonso, J.C.; da Cunha, J.W.S.D. Recovery of platinum from spent catalysts by liquid-liquid extraction in chloride medium. J. Hazard. Mater. 2010, 179, 488-494. [CrossRef]

17. Paiva, A.P.; Ortet, O.; Carvalho, G.I.; Nogueira, C.A. Recovery of palladium from a spent industrial catalyst through leaching and solvent extraction. Hydrometallurgy 2017, 171, 394-401. [CrossRef]

18. Marinho, R.S.; Da, S.C.; Afonso, J.C.; Da, C.J. Recovery of platinum, tin and indium from spent catalysts in chloride medium using strong basic anion exchange resins. J. Hazard. Mater. 2011, 192, 1155-1160. [CrossRef]

19. Hammadi, M.Q.; Yassen, R.S.; Abid, K.N. Recovery of Platinum and Palladium from Scrap Automotive Catalytic Converters. Al-Khwarizmi Eng. J. 2017, 13, 131-141.

20. Britton, L.A.; Markarian, G.Z. Method for platinum recovery from materials containing rhenium and platinum metals. US9702021B2, 11 July 2017.

21. Nogueira, C.A.; Paiva, A.P.; Oliveira, P.C.; Costa, M.C.; Da, C.A. Oxidative leaching process with cupric ion in hydrochloric acid media for recovery of $\mathrm{Pd}$ and $\mathrm{Rh}$ from spent catalytic converters. J. Hazard. Mater. 2014, 278, 82-90. [CrossRef]

22. Aberasturi, D.J.; Pinedo, R.; Larramendi, I.R.; Larramendi, J.I.; Rojo, T. Recovery by hydrometallurgical extraction of the platinum-group metals from car catalytic converters. Miner. Eng. 2011, 24, 505-513. [CrossRef] 
23. Kizilaslan, E.; Aktaş, S.; Şeşen, M.K. Towards environmentally safe recovery of platinum from scrap automotive catalytic converters. Tur. J. Eng. Environ. Sci. 2010, 33, 83-90.

24. Haynes, W.M. CRC Handbook of Chemistry and Physics; CRC Press: Boca Raton, FL, USA, 2014.

25. Li, L.; Fan, E.; Guan, Y.; Zhang, X.X.; Xue, Q.; Wei, L.; Wu, F.; Chen, R.J. Sustainable recovery of cathode materials from spent lithium-ion batteries using lactic acid leaching system. ACS Sustain. Chem. Eng. 2017, 5, 5224-5233. [CrossRef]

26. Li, G.H.; Rao, M.J.; Jiang, T.; Huang, Q.Q.; Peng, Z.W. Leaching of limonitic laterite ore by acidic thiosulfate solution. Miner. Eng. 2011, 24, 859-863. [CrossRef]

27. Bahrami, H.; Eslami, A.; Nabizadeh, R.; Mohseni-Bandpi, A.; Asadi, A.; Sillanpää, M. Degradation of trichloroethylene by sonophotolytic-activated persulfate processes: Optimization using response surface methodology. J. Clean. Prod. 2018, 198, 1210-1218. [CrossRef]

(c) 2019 by the authors. Licensee MDPI, Basel, Switzerland. This article is an open access article distributed under the terms and conditions of the Creative Commons Attribution (CC BY) license (http:/ / creativecommons.org/licenses/by/4.0/). 